\title{
Reflections on internationalization: quo vadis Unioeste?
}

Reflexões sobre internacionalização: quo vadis Unioeste?

\author{
Gabriela Daiana Christ ${ }^{1(\mathbb{D})}$, Samantha Frohlich ${ }^{2}$ (i) Rafael Mattiello $^{3}$ \\ ${ }^{1}$ Universidade Estadual do Oeste do Paraná (Unioeste), Brasil, Mestranda em Desenvolvimento Regional e Agronegócio \\ (PGDRA/Unioeste), Técnica Extensionista no Programa de Qualificação para Exportação (PEIEX-Cascavel), e-mail: \\ gabrielachrist@gmail.com \\ ${ }^{2}$ Universidade Estadual do Oeste do Paraná (Unioeste), Brasil, Doutoranda em Administração (PPGADM-UFPR), professora \\ colaboradora no curso de Secretariado Executivo Trilíngue (Unioeste), e-mail: samantha_0906@hotmail.com \\ ${ }^{3}$ Universidade Estadual do Oeste do Paraná (Unioeste), Brasil, Doutor em Sociologia Política (UFSC), professor adjunto no \\ Centro de Ciências Sociais Aplicadas (Unioeste, campus Cascavel), Assessor de Relações Internacionais e Interinstitucionais \\ (Unioeste), e-mail: rafael.mattiello@unioeste.br
}

\begin{abstract}
Universities are institutions whose commitments go beyond the fields of teaching, research, and outreach. In a society that increasingly requires changes, cooperating with other actors must be a path to be followed. At the same time, internationalization has become a priority appearing on many Higher Education Institutions' agendas. However, it is an open question how universities should manage the new demands proposed by society in a very fast challenging world. Therefore, the aim of this article is to provide a framework for strategic priorities which outlines steps and activities that the Western Paraná State University (Unioeste) should adopt as part of this transformation project through the lens of the Project Model Canvas (FINOCCHIO JUNIOR, 2013). The methodology is characterized as a qualitative study, with an exploratory character, with the collection of data through documentary research. The results show that to operate successfully in the increasingly globalized environment, Unioeste must continue to foster a commitment to internationalization and make significant efforts to integrate the international dimension into key areas of operation.
\end{abstract}

Keywords: Internationalization of higher education. Public university. Higher education policies.

\section{RESUMO}

As universidades são instituições cujos compromissos vão além dos campos do ensino, da pesquisa e da extensão. Em uma sociedade que exige cada vez mais mudanças, a cooperação com outros atores deve ser um caminho a ser percorrido. Paralelamente, a internacionalização passou a ser uma prioridade que aparece na agenda de muitas Instituições de Ensino Superior. No entanto, é uma questão em aberto como as universidades devem gerenciar as novas demandas propostas pela sociedade em um mundo acelerado e desafiador. Portanto, o objetivo deste artigo é fornecer um quadro de prioridades estratégicas que delineie as etapas e atividades que a Universidade Estadual do Oeste do Paraná (Unioeste) deve adotar como parte desse projeto de transformação sob a ótica do Project Model Canvas (FINOCCHIO JUNIOR, 2013). A metodologia caracteriza-se como um estudo qualitativo, de caráter exploratório, com coleta de dados por meio de pesquisa documental. Os resultados mostram que, para atuar com sucesso em um ambiente cada vez mais globalizado, a Unioeste deve continuar a promover o compromisso com a internacionalização e fazer esforços significativos para integrar a dimensão internacional em áreaschave de atuação.

Palavras-chave: Internacionalização do ensino superior. Universidade pública. Políticas de educação superior. 


\section{INTRODUCTION}

Since its creation, universities have been subjected to transformation processes and movements that put their reasons for being in check. The triad of university missions are known as: teaching, research, and outreach. Universities are places of creation and transmission of knowledge and innovation, and are the driving force behind the social, economic, and cultural development of a society. It is the universities that provide the emancipation of the human being, forming critical citizens to act in society (KEMPTON et al., 2021).

It is known that higher education - in times of globalization, strongly accelerated by the end of the Cold War - has been translated into internationalization policies, practices, and discourses. With globalization, a major reconfiguration of economies, trade systems, research and innovation and communications are mandatory (BARLETE, 2019).

The impacts, motivations, and purposes behind this phenomenon of global forces effectively affecting local life, which in turn dramatically expands the need for internationalization, in its most comprehensive form, within higher education institutions around the globe. This is because scientific and technological development is closely linked to institutional participation within this new world logic through its inseparable functions between teaching, research, and outreach (KEMPTON et al., 2021).

Public universities have grown in the last ten years, both in enrollments and in new institutions. But the existence of a crisis and nebulous periods seems to have always existed. The search for solutions is through reforms, processes, and practices that can be increased and improved (ÉSTHER, 2015), in this article we suggest internationalization.

Internationalization has steadily been seen as the fourth mission of the university (SANTOS; ALMEIDA FILHO, 2012) on which its adequate use is continuously conceived as an indispensable tool towards the huge challenges imposed nowadays to Higher Education Institution (HEI) (MCBRIDE; KNUTSON, 2017; RUDZKI, 1998). This inquiry aims at furthering the discussion and facilitating the implementation of internationalization strategies through special attention to specific inputs, processes, and outcomes in a case study, using management tools (FINOCCHIO JUNIOR, 2013) that support the development of internationalization action.

This article aims to provide evidence of how management tools can act as an effective mean to put forward a comprehensive internationalization strategy into newly created 
international offices of HEI through a case study: The Western Paraná State University (Unioeste).

Therefore, the use of selection of management tools in the case of successful experience of setting up a dynamic department taking care of internationalization within the static bureaucracy of Public University in Brazil might present valuable evidence of the effectiveness of the strategy regardless of adversities. In addition to proposing a diagnosis of the past, the study looks to the future "quo Vadis", a term from the Latin that means "where are you going?", in the sense of thinking about an action plan for the institutional success of Unioeste focusing on internationalization.

In response to this trend, we propose a management tool: The Project Model Canvas (FINOCCHIO JUNIOR, 2013) to guide the strategic priorities for Unioeste. In order to properly address this subject, this article is structured, firstly with the present introduction, followed by the theoretical foundation on which we deal with the discussion of internationalization; internationalization of the curriculum; and management and strategies of internationalization methodology, analysis of the results, conclusion, and references.

\section{LITERATURE REVIEW}

This chapter will discuss the concept of internationalization, and management and internationalization strategies.

\subsection{INTERNATIONALIZATION}

The main, and most known missions of the University are guarding and protecting the values of civilization (1), being responsible for producing knowledge (2), providing outreach, transfer, and innovation services (3), internationalization (4). This last one, protagonist of this work, offers us an almost inexhaustible field of opportunities: educational complement for students in all levels of formation (technical preparation, linguistic, cultural, and civilizational formation); individual or group skills; exchange of experiences, assessment of instruments and methods for evaluation of results in all fields of university activity (SANTOS; ALMEIDA FILHO, 2012).

Revista Expectativa, Toledo/PR, v.20, n. 4, p. 108-132, out./dez., 2021. 
The development of a global higher education system is the recognition that a major paradigm shift is taking place, where HEI are not only a strategic resource for local, regional, state, or national development, but a resource connected to world order with all its asymmetries. (BARLETE, 2019; MATTIELLO et al., 2019; KEMPTON et al., 2021). Faced with the mission of universities to prepare citizens for an interconnected and interdependent world, there is a need for a differentiated educational experience.

In this sense, internationalization has become an imperative in HEI in its most comprehensive form, as it provides academics with the opportunity to expand their values in practice, through the exchange of knowledge, culture, and practices, both within the walls of universities and by providing unique experiences through overseas mobility projects (RUDZKI, 1998; ALTBACH; KNIGHT; ALTBACH, 2006; ILLIEVA; BECK; WATERSTONE, 2015; KNIGHT, 2015; STALLIVIERI, 2017; KNIGHT; DE WIT, 2018).

The implementation of policies aimed at the educational sector, involving mobility and experts in strategy, manifests itself with the need to send and develop an intellectual group of academics and professors capable of taking advantage of the process and modernization made available by international academic mobility. This capacity development should be encouraged in the training of academics from public universities (LIMA et al., 2009).

In that regard, internationalization refers to a process of organizational changes, curricular innovation, professional development of the academic staff and administrative team, development of academic mobility in order to seek excellence in teaching, research and other activities that are part the role of universities (RUDZKI, 1998).

Driven by a dynamic combination of political, economic, socio-cultural, and academic rationales and stakeholders, internationalization as a concept and strategy is a relatively new but broad and varied driver of change in Higher Education. Its impact on regions, countries and institutions varies by context, and no single model that fits all (MCBRIDE; KNUTSON, 2017).

De Wit, Leal and Unangst (2020) call attention to the role of universities in the social justice arena, especially in integrating refugees and displaced populations into higher education in Brazilian society. Accordingly, to the authors "Internationalization of higher education has been largely immersed in a competitive, economy-oriented paradigm, potentially reinforcing geographical inequalities of knowledge, power, and being" (DE WIT; LEAL; UNANGST, 2020, p. 13).

Revista Expectativa, Toledo/PR, v.20, n. 4, p. 108-132, out./dez., 2021. 
In this regard, comprehensive internationalization means a commitment and action to infuse international, global, and comparative content and perspective throughout the teaching, research, and service missions of HEI. It shapes institutional ethos and values and touches the entire higher education enterprise. It not only impacts all of campus life, but the Institution's external frameworks of reference, partnerships, and relationships (HUDZIK, 2011). Among the three pillars of internationalization are: mobility (students, academics, administrators, programs, projects, institutions); partnerships (bilateral, multilateral, strategic); and curriculum (knowledge, skills, and attitudes).

Jane Knight (2004, p. 4) claims that "internationalization is changing the world of higher education, and globalization is changing the world of internationalization". In this sense, the process is understood as a continuous and permanent effort, as identified in Table 1 Perspectives in Internationalization.

Table 1 - perspectives in internationalization

\begin{tabular}{|l|l|}
\hline Perspectives & Defining elements \\
\hline As an activity & $\begin{array}{l}\text { International activities that are developed: teaching, research, technical structures and } \\
\text { international students, collaboration programs, inter-institutional agreements, projects } \\
\text { etc. }\end{array}$ \\
\hline As a competence & $\begin{array}{l}\text { New knowledge, competences and skills, students' and professors' attitudes and } \\
\text { values required by internationalization. The focus is on the human dimension rather } \\
\text { than on academic activities or organizational aspects. }\end{array}$ \\
\hline As an ethos & $\begin{array}{l}\text { It assumes a culture that permeates all international and intercultural initiatives. Some } \\
\text { authors consider this perspective as too limited since it does not include details about } \\
\text { how the internationalization objectives could be achieved. }\end{array}$ \\
\hline As a process & $\begin{array}{l}\text { The integration of the international and intercultural dimensions through combining a } \\
\text { series of activities, policy, and procedures. The internationalization appears as an } \\
\text { integration process of different dimensions and activities in Higher Education } \\
\text { Institutions }\end{array}$ \\
\hline
\end{tabular}

Source: Delgado Márquez; Hurtado Torres and Bondar (2011).

Indeed, it is essential that the strategy be embraced by institutional leaders, institutional governance at all levels, by the faculty, by the student body, by university staff, and by all support units. It is an institutional imperative, not just a desirable possibility in the face of contemporary challenges. It not only impacts all aspects of campus life, but the entire external institutional reference pattern through its partnerships and relationships (MATTIELLO et al., 2019).

The institutional commitment to internationalization can potentially permeate all aspects of higher education such as faculty development, curriculum reformulation, instructional 
design, student and faculty diversity, research and scholarship, training and education of external people, welfare development, support services to students and academics, resource development, financial management, risk management, institutional competitiveness, image positioning, and civic engagement (HUDZIK, 2011).

However, internationalization becomes a mission when it achieves its objectives which are: to reinforce joint and integrating projects; give greater scope to their training, research, and innovation activities; conducting an agenda of university cultural diplomacy; contribute to the consolidation of integrated knowledge spaces; and boost cooperation to amplify the work in partnerships (SANTOS; ALMEIDA FILHO, 2012; KESTIN; LUMBRERAS; PUCH, 2020).

The key prerequisites for the successful initiation and implementation of internationalization in their most comprehensive form require clear and consistent leadership from the top of the institution, international engagement of faculty and academic body, persistence and adaptability, and clear and measurable objectives (HUDZIK, 2011).

Thus, internationalization must be a transformative process that integrates the international dimension within the institutional policies to develop skills, attitudes, and values in the pursuit of academic excellence. Among the global trends, there is growing importance of internationalization at all levels (requirement for globally competent graduates and competitive pressures of globalization); trend towards increased privatization through revenue generation; global rankings; growing emphasis on quality assurance and student learning outcomes and more international networks and strategic partnerships. These trends are perceived at the HEIs as: growth in international research (funding, patents, publications, and citations); increased student mobility; increasing mobility of academic staff; increased cross-border education (movement of programs and institutions), educational hubs; and the continued growth of joint/double degree programs (MCBRIDE; KNUTSON, 2017).

Among the main internationalization modalities are mobility of individuals, double degree, sandwich training, cotutelle, integral formation abroad, joint diplomas, and internationalization at home, as conceptualized in Table 2. 
Table 2 - Concepts and modalities of internationalization

\begin{tabular}{|c|l|}
\hline Mobility of individuals & $\begin{array}{l}\text { The student only needs to get acceptance in the university of reception and } \\
\text { authorization of its university of origin. Agreements: proof of attendance, } \\
\text { equivalence plan that recognizes and credits the training that the student will do } \\
\text { abroad. }\end{array}$ \\
\hline Double degree & $\begin{array}{l}\text { Agreement already established between two universities that undertake, completing } \\
\text { the training, to grant them their degrees and issue the corresponding diplomas. }\end{array}$ \\
\hline Sandwich training & $\begin{array}{l}\text { The stay of the student abroad is preceded by an initial period at his home university, } \\
\text { to which he returns to complete his studies. }\end{array}$ \\
\hline Cotutelle & $\begin{array}{l}\text { It is necessary to find for each of the students involved in a mobility program (with } \\
\text { more emphasis on master's and doctoral programs in double degree or joint diploma) } \\
\text { a co-responsible scientist, professor, or coordinator in the university of origin and } \\
\text { another one in the university of destination. }\end{array}$ \\
\hline Integral formation \\
abroad & $\begin{array}{l}\text { Students apply and attend without any connection to a university of their own country } \\
\text { of origin. It represents a conscious and voluntary action of a student or a university } \\
\text { for later use of its competences. }\end{array}$ \\
\hline Joint diplomas & $\begin{array}{l}\text { Universities decide to issue, together, the same diploma. The design of this program } \\
\text { must be done in compliance with the legal and regulatory frameworks in force in each } \\
\text { of them. }\end{array}$ \\
\hline Internationalization at \\
home & $\begin{array}{l}\text { It means engaging students with teaching and research at the international level, with } \\
\text { cultural and linguistic diversity, whose aim is to develop international and } \\
\text { intercultural perspectives as global citizens (LEASK, 2009). }\end{array}$ \\
\hline
\end{tabular}
Source: Adapted from (SANTOS; ALMEIDA FILHO, 2012).

Among the advantages of mobility of individuals is not needing notwithstanding the passing of the corresponding diploma, the commitment of the host university can be restricted to the pedagogical and scientific fields. Mobility can take the form of an academic or professional internship or can be done through a study plan previously defined by mutual agreement between universities (SANTOS; ALMEIDA FILHO, 2012).

On the other hand, a double degree requires closer proximity between universities and requires mutual trust in the quality of training and political and administrative work that forms part of the mobility program, which is usually aimed at more people. The most successful mobility program - joint degrees - reveals a mature culture for mobility, which may seem like a small step for the student, but effectively corresponds to a huge leap for the whole conceptual building of mobility (SANTOS; ALMEIDA FILHO, 2012).

Curricular internationalization is strictly related to the idea of internationalization at home, which corresponds to the activities of an international nature that happen in the institution of origin, except for the exit of a member of the community to achieve mobility (LEAL; MORAES, 2016).

The purpose of concept of internationalization at home, other than the direct practice of assimilating experiences and knowledge through international mobility, resides in the first 
contact with an international academic and professional community through digital media, in the development of work plans abroad and in the construction of networks a priori, aiming both at establishing contact with internationalized professionals and academics in the country of origin as well as in the country visited (STALLIVIERI, 2017).

Corroborating with the concept of internationalization at home, Knight (2004) attributes its importance to raising the internal elements of the university, with an emphasis on the international, intercultural, and global dimensions that are established in teaching, research, outreach activities, relationships with the local community, as well as the integration of the foreign community into activities and life on campus.

Regarding the expected results, the literature on curricular internationalization indicates "global citizenship" and "intercultural competence" as the main ones, mainly because they are associated with the preparation of students to live and work in a globalized and interconnected world (LEAL; MORAES, 2016). Intercultural competence refers to the ability to communicate and behave in social and professional situations facing different cultures.

For Baldassar and McKenzie (2016), an important factor in the internationalization of the curriculum is the provision of courses focused on the international dimension or disciplines taught in English, but they do not guarantee the internationalization of the curriculum, nor do they guarantee the students the expected competences. The learning of foreign languages is relevant for appreciation of other cultures, but the main objective is to understand the diversity of values, points of view and mental framework existing around the world.

Curricular internationalization requires analysis, comprehension and improvement in its conception and practice, which incorporate considerations regarding the roots and sets of the various scientific knowledge in the contexts where it occurs (LEAL; MORAES, 2016).

The understanding of the internationalization of higher education in Brazil, according Knobel et al., (2020, p. 13) "has evolved from being synonymous with international academic mobility, focused on individuals, to a more comprehensive conception of the process, focused on transforming the university institution in the molds established in the hegemonic international environment." (Own translation). 


\subsection{MANAGEMENT AND INTERNATIONALIZATION STRATEGIES}

De Wit and Hunter (2014, p. 8) argue that "internationalization in universities shifts from being a marginal to mainstream activity, no longer located exclusively in the international offices, but an integral part of University strategy." About this change and the competitive environment, the Higher Education Internationalization Data Report (HEIDA, 2015, p. 15) says that "these changes are leading towards an increasingly competitive market [...]. The traditional methods of governance of education systems and institutional management are no longer appropriate".

In this context, McBride and Knutson (2017) define eight (8) key considerations for internationalization strategies:

a) Alignment with the institutional vision, strategic plan, research framework and the unique needs of the institution.

b) Mapping the stakeholder landscape: who is implicated in the internationalization process and in what ways they need to be part of this process.

c) Consultations with internal and external stakeholders.

d) Development of an internationalization vision, strategic directions, and objectives.

e) Examining internal and external resources available.

f) Development of an action plan, including key markets, targets, opportunities, and performance indicators.

g) Engagement of deans, academic units, faculty members and students during implementation.

h) Managing implementation (performance measurement, feedback gathering and plan adjustment).

Juha Kettunen (2008, p. 323) defines "the successful evaluation of institutional performance means that there must be a general and common conceptual framework to describe and evaluate performance" and also "the management process is a series of management activities which include four sequences of management: strategic management and the updating of strategic objectives, the planning of operations and resources, the operations and steering and the reporting of results" (p. 325), and to conclude the idea the author summarize "... strategic management is a strong candidate for inclusion in the framework to evaluate institutional performance" (p. 327).

Revista Expectativa, Toledo/PR, v.20, n. 4, p. 108-132, out./dez., 2021. 
Internationalization is a necessary strategy to enhance the quality and relevance of education and research, and of their service to society, at the local, national, and global levels (MCBRIDE; KNUTSON, 2017). In that sense, we selected one management tool to subsidize the setting up of the internationalization strategy of Unioeste: The Project Model Canvas.

\section{METHODOLOGICAL PROCEDURES}

This research developed in five main stages: the first one (of a theoretical and conceptual character and based on a literature review on the theme). The second stage was to collect secondary data obtained from official sources, namely: www.unioeste.br. After data collection, in the third and fourth stages, the database's organization and the application of the model used, proposed by Finocchio Junior (2013), were carried out. At last, the fifth stage was conducted with the analysis of the results.

The research is characterized as a descriptive case study since it does not allow direct quantification of variables through statistical resources. The research used a qualitative approach, with an exploratory character. It is noteworthy that qualitative studies make it possible to understand and detail aspects related to what is studied in greater depth (STAKE, 2005; CRESWELL, 2007; GIBBS, 2009).

To achieve the proposed objective, the researchers used secondary data (STAKE, 1995) with the collection of data through documentary research, which, works the data seeking its meaning, based on the perception of the phenomenon within its context (OLIVEIRA, 2007).

The case study (YIN, 2005) was used as a research method, whose protagonist is the Unioeste, Public Institution of Higher Education, specifically the International Office, an advisor body for the Rectory. For the authors, the case study is one of the forms of research identified in the social sciences aimed at understanding complex social phenomena and allows a meaningful investigation of real-life events. It is also a way of conducting research investigating current phenomena within their real context, in situations where the boundaries between phenomenon and context are not clearly established. In the case study method, data collection techniques can be obtained from primary and secondary data through documentation, records, minutes of meetings made available by the organization, observations, and interviews (YIN, 2005). 
To achieve the objective the authors defined one management tool to analyze and set strategic priorities, which are the Project Model Canvas (PMC) which are commonly used to define and manage projects, on this opportunity named as "International Office Unioeste Strategic Plan" whose product conceived is "Strategic management of International Office". The Project Model Canvas, where an integration protocol is proposed, considers project management theory, whose components are grouped in fundamental questions (FINOCCHIO JUNIOR, 2013).

The Canvas in question is an agenda on which the interested parties will be dedicated to conceiving the logic of the project, whose importance is in the relations between the concepts. It is organized into five blocks that seek to answer the questions:

a) The first block is "Why": for the author who proposed the method (FINOCCHIO JUNIOR, 2013), every project defends a change from the current situation to a desirable situation, so the first block proposes to answer the question "Why?" through three affirmations: Justification (problem that the organization faces and what needs are not met); SMART objectives (summarize the goal so that it is specific, measurable, attainable, realistic, timed); and Benefits (describe what will be achieved after the implementation of the project).

b) The second block is "What": represents the demand, and is divided into two propositions, namely: Product (result of the project, can still generate a service or a unique result), and requirements (defines the quality that the product - service / result - needs to present value to the customer).

c) The third block is "Who": it has two components, Stakeholders (people or external factors involved that are not subordinated to the project manager can affect the project and must be listed) and Team (all participants who are responsible for producing the projects).

d) The fourth block, meaning the team's work in response to demand, has a pragmatic function of answering the "How?": Question, through three drivers: Assumptions (assumptions given as right about the environment and factors external to the project, which are not under the control of the project manager); Delivery group (concrete, measurable and tangible components that will be generated by the project); and Restrictions (describe project limitations of any nature and origin that will impact the development of teamwork).

e) The last block corresponds to the questions "When and How Much?" and are divided into three assertions: Risks (future and uncertain events that have relevance to the project, here the risks of the project are identified and analyzed); Timeline (when deliveries will occur, linked to the previous block, delivery group); and Costs (information on estimated costs for each project delivery group).

Revista Expectativa, Toledo/PR, v.20, n. 4, p. 108-132, out./dez., 2021. 
It is recommended that the Canvas be built on a single sheet of format A1 and selfadhesive notes (post-its), with a maximum of 140 characters per note. Such methodology allows flexibility for modification and highlights that the more creative and connected the team is, the better the result will be (CHRIST; ARAÚJO, 2020). The dynamics of the tool's construction do not have predefined roles, but it is recommended that the members know the tool and have basic concepts of project management.

Finally, the data were formed with the aid of content analysis, which can be defined as the research method that allows the interpretation of subjective aspects regarding the content of the data collected, being done through a set of diversified methodological instruments that apply to different types of speech (SALDAÑA; OMASTA, 2016).

\section{DISCUSSION AND ANALYSIS}

This chapter will explore the Paraná State, the Western Paraná State University, The International Office, and the Framework for strategic priorities: The Project Model Canvas.

\subsection{THE PARANÁ STATE}

The State of Paraná is one of the 27 federative units of Brazil, and it is in the Southern Region of Brazil, neighboring the States of Santa Catarina, São Paulo, Mato Grosso do Sul and the countries of Argentina and Paraguay. Its area is $199.298,982 \mathrm{~km}^{2}$, slightly smaller than Romania, and figures as the 5th richest State in Brazil (Brazilian Institute of Geography and Statistics - IBGE, 2020). The Superintendence of Science, Technology and Higher Education (SETI) is the governmental body responsible for the State of Paraná. On the other hand, it drives technological progress and innovation by ensuring support for the development and improvement of companies that face an increasingly specialized and competitive market.

Also, the State has a university structure that embraces seven universities (Figure 1), 100 thousand students, $\mathrm{R} \$ 2,5$ billion in annual investments and highly skilled researchers from a system of higher education ranked among the best in Brazil and the world (SETI, 2021). All the seven State Universities of Paraná are in strategic places and play an important role in the regional development of their region.

Revista Expectativa, Toledo/PR, v.20, n. 4, p. 108-132, out./dez., 2021. 
Figure 1 - State Universities of Paraná

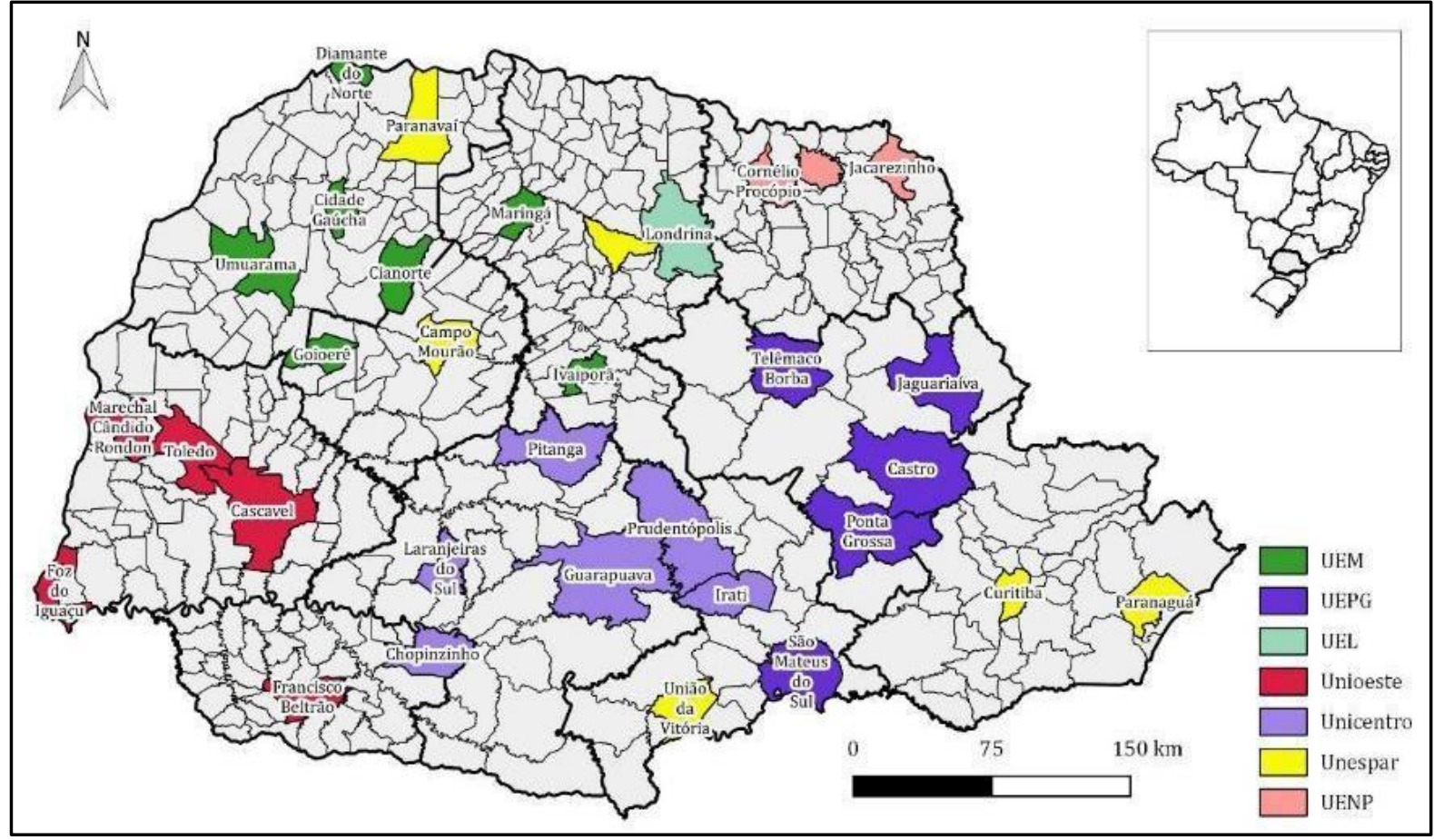

Source: made by the authors, 2021.

The Paraná State Public Higher Education Institutions Association (APIESP) is an entity that unites the seven public State Universities of Paraná. It was created in 1994 and its head offices are in Curitiba City. APIESP aggregates the State University of Maringá (UEM, established in 1969), State University of Ponta Grossa (UEPG, established in 1969), State University of Londrina (UEL, established in 1971), Western Paraná State University (UNIOESTE, established in 1994), Midwestern State University (UNICENTRO, established in 1996), State University of Northern Parana (UENP, established in 2006) and State University of Paraná (UNESPAR, established in 2006). APIESP's main goal is to defend the public higher education institutions' interests at the State Government, the Federal Government, and the municipalities (SETI, 2021).

\subsection{THE WESTERN PARANÁ STATE UNIVERSITY}

The Western Paraná State University (Unioeste), authorized by State Law No. 8,680, of December 30, 1987 and accredited by the Ministry of Education (MEC) Ministerial Ordinance No. 1784-A dated December 23,1994, published in the Federal Official Gazette on December 28,1994 - is a state non-profit organization with a multi-campus structure, with public legal 
status of the Rectory and forum in the city of Cascavel, State of Paraná, linked to the State Superintendence for Science, Technology and Higher Education - SETI (UNIOESTE, 1999).

The university, with its own patrimony and income, has a didactic-scientific, administrative, financial, and patrimonial and disciplinary autonomy, being governed by Statute, by the General Regulations, by the resolutions of the Superior Councils, obeying federal and state legislation. The university mission is to produce, systematize and socialize knowledge, adding to human, scientific, technological, and regional development, committing with justice, democracy, citizenship, and social responsibility (UNIOESTE, 1999).

As a HEI in a border region, Unioeste has sought primarily to establish strong partnerships with universities and institutions around the world, building together a space of constant internationalization. Unioeste is an HEI strategically located in the Western and Southwestern regions of Paraná, located in the Triple Border (Paraguay-Argentina-Brazil). Thus, in addition to the research carried out in the agro-industrial development of the region, a notorious field of research is the studies related to the borders. In congruence, as pointed out by authorities on the topic of cooperation (BARLETE, 2019; KESTIN; LUMBRERAS; PUCH, 2020; SANTOS; ALMEIDA FILHO, 2012).

Conceiving the importance of developing academic partnerships with neighboring border countries, Unioeste's participation in the Zicosur Network (Integration Zone of CentralWest South America) is established as an important factor for the integration and articulation of regional partnerships. Other groups and organizations whose primary goal for internationalization has also been presented as key partners, such as the Association Internationale des Étudiants en Sciences Economiques et Commerciales (AIESEC), the Brazilian Association for International Education (FAUBAI) and the Erasmus Mundus Project.

Besides regional partnerships with South America, Unioeste also has existing cooperation agreements with HEIs in Europe, North America and Africa (Germany, Canada, Spain, Finland, France, Italy, Norway, The United Kingdom, Sweden, Romania, Portugal, the United States of America, Mexico and Ivory Coast), whose partnering work has provided several opportunities for professor and student mobility, such as research projects, postgraduations, and partnerships in the mutual development for the internationalization, cosupervising etc.

In December 2020, Unioeste had 11,485 undergraduate students, divided into 64 courses; 2,257 postgraduate students (Lato and Stricto Sensu), enrolled between 32 stricto sensu 
courses (professional), 37 master's degrees and 17 doctorates; 1,930 university agents (effective, intern, trainees and outsourced); and 1,185 faculty members (UNIOESTE, 2021a). The evolution of the offer of courses is a highlight of the current management, as shown in Figure 2 Evolution of the academic offer.

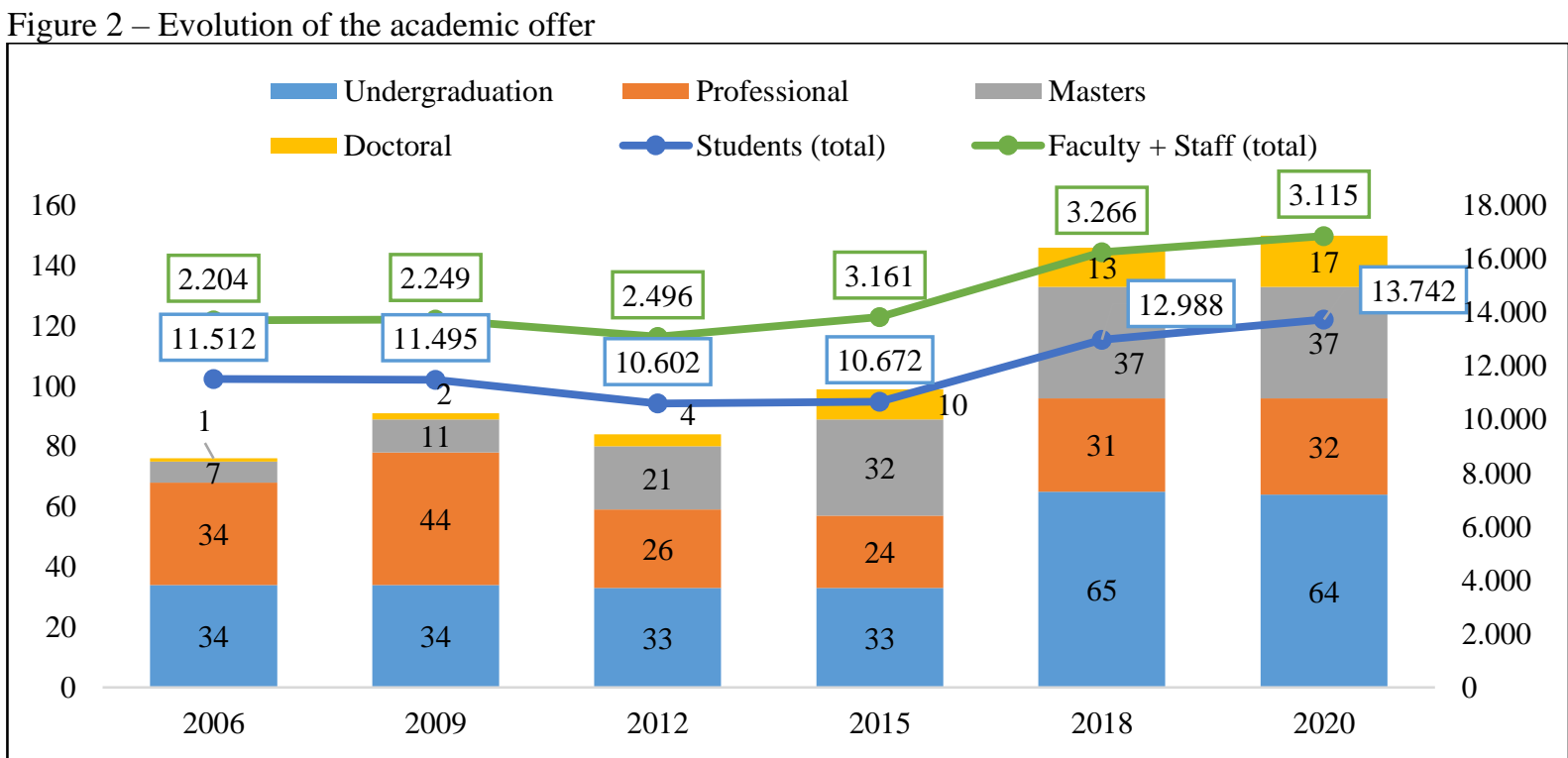

Source: made by the authors, by the data from Unioeste (2021a).

In addition to its contribution as an important actor for regional development, mainly in the teaching (education), knowledge production (research) and engagement with the community (outreach) (KEMPTON et al., 2021) Unioeste is an institution that in 2021 approved a budget in the order of $\mathrm{R} \$ 824,491,304$, considering all its units and sources of funds. The evolution of the budget is shown in Figure 3. 
Figure 3 - Evolution of the budget

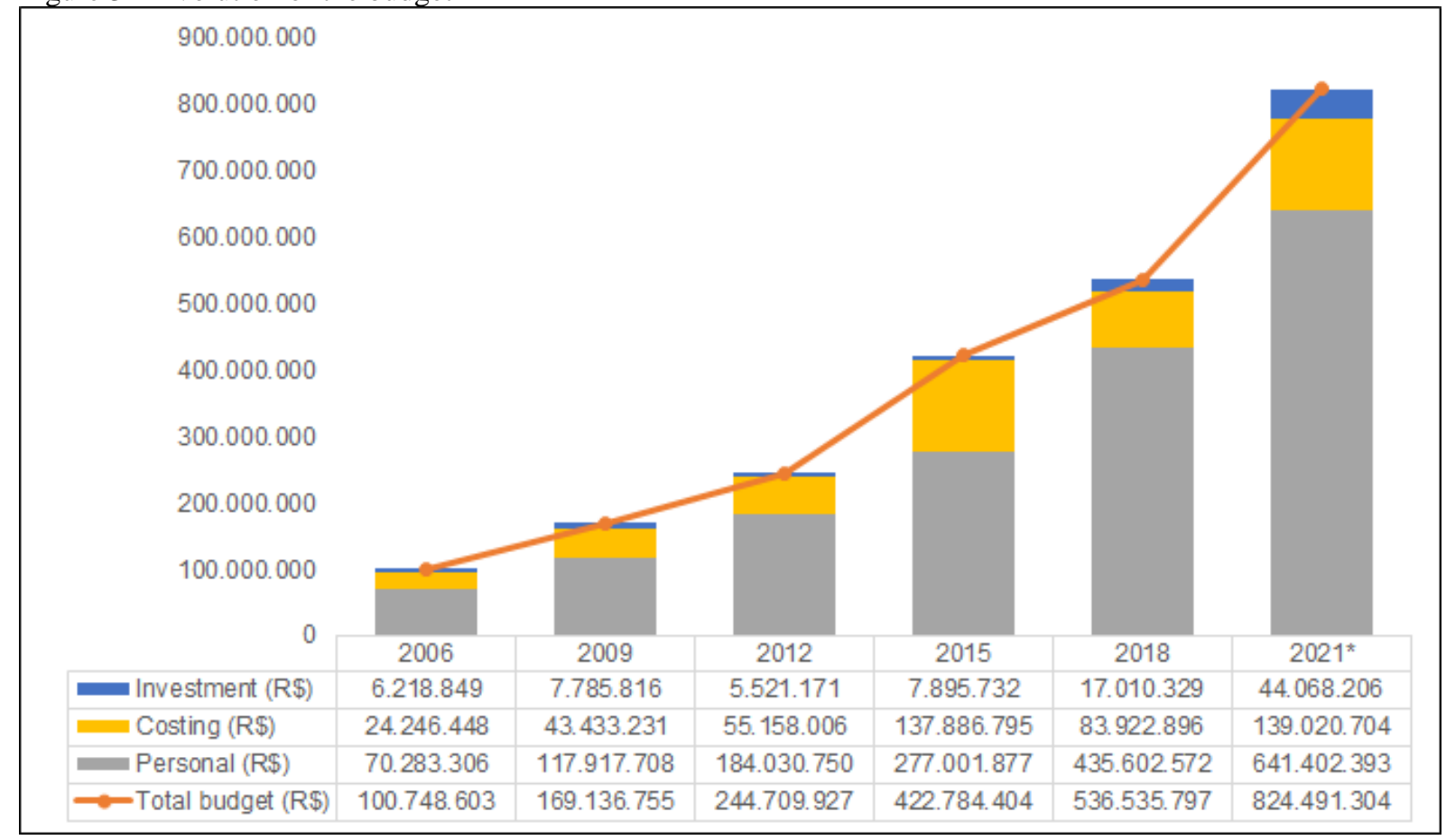

Source: made by the authors, by the data from UNIOESTE (2021b, 2021c).

* Unioeste's budget proposal for fiscal year 2021.

In other words, Unioeste is a strategic institution for the region where it operates, Western and Southwest of Paraná, especially for promoting regional development and contributing with human capital, social capital, intellectual capital, knowledge production, innovation, and cultural capital. After the contextualization of Unioeste, the next topic will address the role of the International Office within the university.

\subsection{THE INTERNATIONAL OFFICE}

The University's International Office is committed to cross-cutting inter-agency and international cooperation at all levels through undergraduate and graduate programs in research, innovation, and outreach. This strategy seeks to create a multicultural environment on the campuses, on the one hand, with the best universities in the world and, on the other hand, consolidating its postulation as a reference Institution in Latin America. The purpose / mission is, based on the premise of "learning by doing," to establish the basis for the consolidation of an institutionalized strategy, independently of management, that seeks to maximize organizational interests in Interinstitutional and International Relations (UNIOESTE, 2020a). 
At the same time, it is possible to observe the formulation of homogenizing policies that affect universities, the outline of a new process of transformation, or even of "transnationalization," as the university begins to feel the pressure of States, societies, and the market in context of the new stage of globalization and international competitiveness that has led to the need for integration with other countries to build regional blocs (MATTIELLO et al., 2019).

Among the axes established in the internationalization policy (UNIOESTE, 2017) are: Expansion of agreements of international cooperation with institutions of recognized academic prestige; Increase of the active participation of Unioeste students and professors in foreign institutions of recognized academic prestige; Increased participation of foreign students and teachers in Unioeste; Involvement of teachers and technicians with the internationalization process; and Expansion of the internationalization structure in Unioeste.

As suggest Kestin, Lumbreras and Puch (2020), universities should create new organizational units to house most of the challenges faced in our time. Following the internationalization policy of Unioeste, we understand that this contributes to the direction of where Unioeste intends to go. Having an International Office to monitor internationalization, as in the case of Unioeste, is an action that we deem appropriate for the good performance of the university in the face of internationalization demands.

\subsection{FRAMEWORK FOR STRATEGIC PRIORITIES: THE PROJECT MODEL CANVAS}

Considering the mission of the International Office - which, based on the premise of learning by doing, seeks to establish the basis for the consolidation of an institutionalized strategy, independently of management, aiming to maximize the organizational interests in Inter-institutional and International Relations of Unioeste - objective of this work, which is to envisage alternatives to the strategic management of the International Office (Assessoria de Relações Internacionais e Interinstitucionais / Unioeste), The Project Model Canvas (Figure 4) is proposed. 
Figure 4 - Project model canvas: International Office UNIOESTE

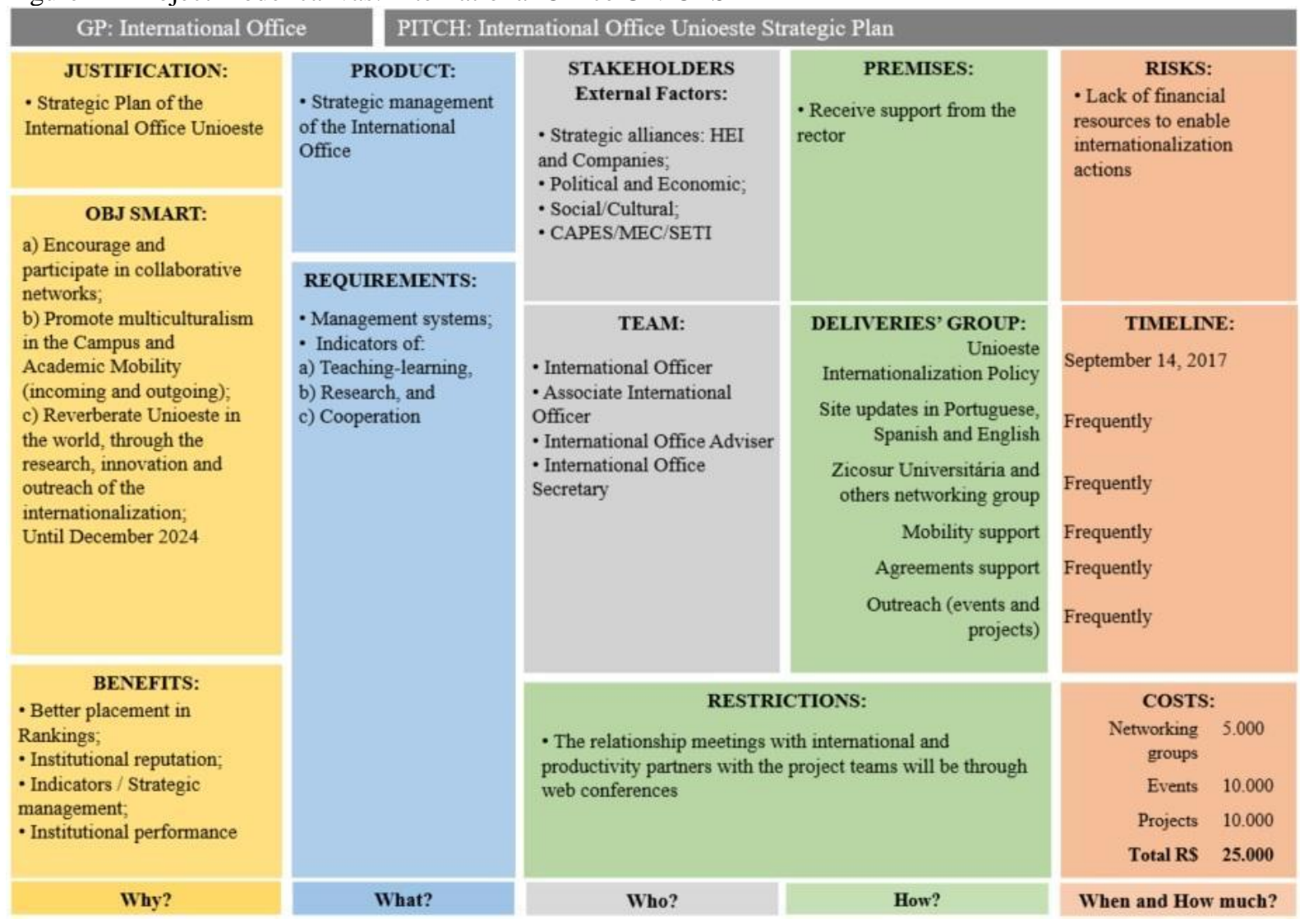

Source: made by the authors, from Finocchio Junior (2013).

The "WHY" of the project is related to justification is to establish the strategic planning of the Intl. Unioeste Office. The SMART (specific, measurable, achievable, relevant and time bound) its objective has three (3) aspects: Encourage and participate in collaborative networks; Promote multiculturalism in the Campus and Academic Mobility (incoming and outgoing); and Disclosure Unioeste in the world, through the research, innovation, and outreach of the internationalization; Until December 2019. Finally, the benefits are: better placement in Rankings; Institutional reputation; Indicators / Strategic management; Institutional performance.

The "WHAT" is divided into two aspects: product defined as Strategic management of the International Office; and requirements Management systems; Indicators of: Teachinglearning, Research, and Cooperation. These, in turn, are fundamental for decision-making and management of the International Office. 
The actors in the project, namely "WHO", are stakeholders and external factors Strategic alliances: HEI and Companies; Political and Economic; Social / Cultural; Coordination of Superior Level Staff Improvement (CAPES), Ministry of Education (MEC), and SETI; and staff, represented by the International Officer, Associate International Officer, International Office Adviser, and International Office Secretary.

There are three (3) items that represent "HOW": premises (receive support from the Rector, i.e. without this it is not possible to carry out the project); groups of deliveries (Unioeste internationalization policy, site updates in Portuguese, Spanish and English, ZicoSur university and others networking group, mobility support, agreements support, and outreach: events and projects); and restrictions (the relationship meetings with international and productivity partners with the project teams will be through web conferences).

The last items of the model refer to "WHEN AND HOW MUCH," represented by: risks (lack of financial resources to enable internationalization actions); timeline, the current mandate of the rectory's management is scheduled for December 2024; and budget, foreseen a total of US\$ 25,000.00 for maintenance of work networks, such as ZicoSur Universitária, realization and participation of events and projects.

In this chapter, we proposed a framework for strategic priorities to the International Office of Unioeste. Planning is a good start for setting priorities and define the "quo Vadis". If Unioeste wants to maintain its prominent position in conducting regional agendas and extrapolate the geographic limits where it operates, cooperates with other institutions, encourages the international mobility of people, share methods and good practices with other actors is suggested.

\section{CONCLUSION}

Internationalization is a challenge of the globalized contemporary scenario. Partnerships allow the exchange of knowledge and the strengthening of the parties involved. Through international relations, there is a strengthening of local values from global exchanges. With the challenge of expanding its activities through actions proposed in the internationalization plan, Unioeste is committed to internationalization and seeks to develop it in an active, participative, and plural manner.

Revista Expectativa, Toledo/PR, v.20, n. 4, p. 108-132, out./dez., 2021. 
This paper aimed to provide evidence of how management tools can act as an effective means to put forward a comprehensive internationalization strategy, especially focusing on the Unioeste case. Internationalization should not be understood as an end, but as a mean to achieve the goals. And yet, the International Offices should not be understood as a department, but rather as a behavior. In this sense, understanding internationalization as the constant process of building university development, seeking to establish international cooperation aimed at showing abroad that institution of higher education as a consolidated center of production and scientific dissemination.

It becomes indispensable the development, application and improvement of internationalization strategies, such as institutional representation in international cooperation networks, participation in international academic and scientific events, the attraction of academic and international professionals to the institution of origin, the achievement of academic mobility, whether through double degree courses, sandwich training, international comprehensive training, training of co-tutelage, or through theoretical and empirical strategies, such as the development of physical materials for dissemination of the institution and its projects in the foreign language platforms, digital platforms for dissemination of the institution and its projects, internationalization at home and consolidation in rankings and lists of institutions that seek to build the internationalization of its institution.

The Unioeste's internationalization policy foresees the internationalization increasing at the undergraduate and graduate curricula, amplifying the communication possibilities of the student beyond his or her linguistic community, heightening awareness about the contextual, social, cultural, and historic heterogeneity in the use of any language.

Broadly, the satisfactory performance of the International Offices is a critical factor for the success of the university. Therefore, we seek alternatives to the conduct of strategic planning, which can generate effective results of management of the International Office Unioeste, both to the internal academic community (faculty, staff, students) and to the global institutional level.

The curricula internationalization will have as its main goal to involve the students with informed international research, as well as the cultural and linguistic diversity, besides purposely develop their intercultural and international perspectives as global citizens and professionals, aiming to value the intercultural relations and social inclusion, taking as reference the integral formation, the respect to linguistic and cultural diversity, as well as to solidarity.

Revista Expectativa, Toledo/PR, v.20, n. 4, p. 108-132, out./dez., 2021. 
This institutionalization process of internationalization of the curricula, with the graduation program curricula structure of materials and disciplines in foreign language, aims to provide the improvement of languages through intercultural experiences, raising awareness on the students, professors, and employees that there are many ways to organize, categorize and express human experience, as well as to make social interactions through language.

Besides that, the use of materials and themes in foreign language develops the linguistic and cultural sensibility in the academic community, while helps in the development of a multicultural and multilingual environment between the intern and international community. The amplification of formative spaces, through Unioeste's curriculum internationalization helps the academic community in the use of foreign languages for scientific work presentation, for both oral and written modality, reverberating the institution internationalization process, and the most important integrating the international dimension into the key areas of operation, motivating people to cooperate towards a common goal.

In this context, developing, making use of management tools, such as the Project Model Canvas, is highly recommended to measure and evaluate the performance of the business. These tools are also useful as a basis for generating other documents, such as presentations, schedules, budgets, and serves as plans for new projects.

As a practical contribution, the study presented a Project Model Canvas to International Office of Unioeste, which can work as a subsidy to promote actions to encourage the internationalization of public universities and suit possible management demands, as well showed the relevance of Unioeste for the region where it operates. As a theorical contribution, it emphasizes the advance in relation to studies aimed at the internationalization of public universities.

As any forms of policies, if they are not evaluated in their implementation, they will not be successful. The limitation in the execution of strategic plans for defining priorities is not being embraced by leaders and led within the institution. More than building a strategic plan together, it is necessary to act to put it into practice to arrive at the desired place.

For future research, it suggests the evaluation of activities related to virtual mobility and other actions performed by the International Office during the Covid-19 pandemic. 


\section{REFERENCES}

ALTBACH, P.; KNIGHT, J.; ALTBACH, P. Visión panorámica de la internacionalización en la educación superior: motivaciones y realidades. Perfiles educativos, v. 28, n. 112, p. 13-39, 2006.

BALDASSAR, L.; MCKENZIE, L. Beyond "Just Being There": Teaching Internationalization at Home in Two Qualitative Methods Units. Teaching Sociology, v. 44, n. 2, p. 84-95, 2016.

BARLETE, A. R. L. A cultural political economy account of higher education in Mercosur. Doctoral thesis (Wolfson College, Faculty of Education) - Cambridge: University of Cambridge, 2019.

CHRIST, G. D.; ARAÚJO, M. P. Aplicação do Project Model Canvas com ênfase no comércio exterior. In: RAMOS, A. A. C. et al. (Eds.). Ensaios PEIEX 2020. 1. ed. Brasília: Apex-Brasil, 2020. p. 44-46.

CRESWELL, J. W. et al. Qualitative research designs: Selection and implementation. The counseling psychologist, v. 35, n. 2, p. 236-264, 2007.

DE WIT, H.; HUNTER, F. Europe's 25 Years of Internationalization: The EAIE in a Changing World. International Higher Education, n. 74, p. 14-15, 2014.

DE WIT, H.; LEAL, F. G.; UNANGST, L. Internationalization Aimed at Global Social Justice: Brazilian University Initiatives to Integrate Refugees and Displaced Populations. In: ENCONTRO DA ASSOCIAÇÃO NACIONAL DE PÓS-GRADUAÇÃO E PESQUISA EM ADMINISTRAÇÃO. 44., on-line. Anais eletrônicos [...] Maringá: Associação Nacional de Pós-Graduação e Pesquisa em Administração, 2020. Disponível em:

http://anpad.org.br/abrir_pdf.php?e=MjkwMjg=. Acesso em: 4 jun. 2021.

DELGADO MÁRQUEZ, B.; HURTADO TORRES, N.; BONDAR, Y. La internacionalización en la enseñanza superior: investigación teórica y empírica sobre su influencia en las clasificaciones de las instituciones universitarias. RUSC. Universities and Knowledge Society Journal, v. 8, n. 2, p. 101-122, 2011.

ÉSTHER, A. B. Que universidade? Reflexões sobre a trajetória, identidade e perspectivas da universidade pública brasileira. Espacio, Tiempo y Educación, v. 2, n. 2, p. 197-221, 2015.

FINOCCHIO JUNIOR, J. Project Model Canvas: Gerenciamento de Projetos sem Burocracia. $1^{\text {a }}$ ed. Rio de Janeiro: Elsevier/Campus, 2013.

GIBBS, Graham. Análise de dados qualitativos: coleção pesquisa qualitativa. Bookman Editora, 2009. 
HEIDA. Bridging the gap between faculty and admin using effective communication platforms Literature review. Relatório. Istanbul, 2015. Disponível em:

https://heida.ku.edu.tr/wp-content/uploads/2018/08/HEIDA_Project-Output-1-LiterartureReview-25.5.2015.pdf. Acesso em: 3 jun. 2021.

HUDZIK, J. K. Comprehensive internationalization: From concept to action. NAFSA ePublications, p. 1-42, 2011.

IBGE. Cidades e Estados. Disponível em: https://www.ibge.gov.br/cidades-e-estados/pr/. Acesso em: 3 jun. 2021.

ILLIEVA, R.; BECK, K.; WATERSTONE, B. Towards sustainable internationalisation of higher education. International Higher Education, v. 22, n. 2, p. 13-39, 2015.

KEMPTON, L. et al. Regional Studies Policy Impact Books. London: Taylor \& Francis Online, 2021. v. 3.

KESTIN, T.; LUMBRERAS, J.; PUCH, M. C. Accelerating Education for the SDGs in Universities. New York: Sustainable Development Solutions Network, 2020.

KETTUNEN, J. A conceptual framework to help evaluate the quality of institutional performance. Quality Assurance in Education, v. 16, n. 4, p. 322-332, 2008.

KNIGHT, J. Five Truths about Internationalization. International Higher Education, n. 69, p. 4-5, 2015.

KNIGHT, J. Internationalization Remodeled: Definition, Approaches, and Rationales. Journal of Studies in International Education, v. 8, n. 1, p. 5-31, 2004.

KNIGHT, J.; DE WIT, H. Internationalization of Higher Education: Past and Future The Center for International Higher Education (CIHE). International Higher Education, v. 95, p. 9-11, 2018.

KNOBEL, M. et al. Desenvolvimentos da Internacionalização da Educação Superior no Brasil: Da Mobilidade Acadêmica Internacional à Institucionalização do Processo na Universidade. In: ENCONTRO DA ASSOCIAÇÃO NACIONAL DE PÓS-GRADUAÇÃO E PESQUISA EM ADMINISTRAÇÃO. Anais [...] Maringá: Associação Nacional de PósGraduação e Pesquisa em Administração, 2020. Disponível em: http://anpad.org.br/abrir_pdf.php?e=MjkwMjc=. Acesso em: 4 jun. 2021.

LEAL, F. G.; MORAES, M. C. B. Internacionalização do currículo: um olhar crítico fundamentado no pensamento complexo. Internacionalização do currículo: educação, interculturalidade, cidadania global, May, 2016.

MATTIELLO, R. et al. Protagonismo na internacionalização da Unioeste. In: EYNG, C. et al. (Eds.). Ciências agrárias: ensino, cooperativismo, segurança alimentar e sucessão na agricultura. 1. ed. Marechal Cândido Rondon: Centro de Ciências Agrárias, 2019. v. 1, p. 
$109-118$.

MCBRIDE, K.; KNUTSON, S. Strategic Internationalization of Higher Education. Canadian Bureau of International Education. 2017. Disponível em: https://cbie.ca/learning/training/internationalization-higher-education-canada/. Acesso em: 13 jul. 2017.

OLIVEIRA, M. M. Como fazer pesquisa qualitativa. Petrópolis: Vozes, 2007.

RUDZKI, R. E. J. The strategic management of internationalization towards a model of theory and practice. March, p. 331, 1998.

SANTOS, F. S.; ALMEIDA FILHO, N. A quarta missão da Universidade: internacionalização universitária na sociedade do conhecimento. Brasília: Editora Universidade de Brasília; Coimbra: Imprensa da Universidade de Coimbra, 2012.

SALDAÑA, J.; OMASTA, M. Qualitative research: Analyzing life. Sage Publications, 2016.

SETI. Superintendência Geral de Ciência, Tecnologia e Ensino Superior. Disponível em: http://www.seti.pr.gov.br/institucional/apresentacao. Acesso em: 24 maio. 2021.

STALLIVIERI, L. Understanding the internationalization of higher education. Revista de EDUCAÇÃO do Cogeime, v. 26, n. 50, p. 37, 2017.

STAKE, R. E. Qualitative case studies. 2005.

LIMA, M. C.; MARANHÃO, C. M. S. A. O sistema de educação superior mundial: entre a internacionalização ativa e passiva. Avaliação: Revista da Avaliação da Educação Superior (Campinas), v. 14, n. 3, p. 583-610, 2009.

UNIOESTE. Estatística - Unioeste em números. Disponível em:

https://www.unioeste.br/portal/acesso-aos-dados/estatistica. Acesso em: 11 fev. $2021 \mathrm{a}$.

UNIOESTE. Estatuto da Universidade Estadual do Oeste do Paraná: Resolução N ${ }^{o}$ 017/1999-COU, de 17 de setembro de 1999. Disponível em:

https://www.unioeste.br/portal/arquivos/scs/docs/017_estatuto.pdf. Acesso em: 26 out. 2020.

UNIOESTE. Orçamento Executado. Disponível em:

https://www.unioeste.br/portal/transparenciaproplan/planejamento-e-orcamento/orcamentoda-unioeste/orcamento-aprovado. Acesso em: 27 maio. 2021 b.

UNIOESTE. Política de Internacionalização da Universidade Estadual do Oeste do Paraná: Resolução N 134/2017-COU, de 14 de setembro de 2017. Disponível em: https://midas.unioeste.br/sgav/arqVrtConteudo/download?arqCntCodigo=560. Acesso em: 26 out. 2020.

Revista Expectativa, Toledo/PR, v.20, n. 4, p. 108-132, out./dez., 2021. 
UNIOESTE. Resolução No 057/2020-COU, de 12 de maio de 2020 (Aprova a proposta orçamentária da Unioeste para o exercício de 2021). Disponível em:

https://midas.unioeste.br/sgav/arqVrtConteudo/download?arqCntCodigo=207747. Acesso em: 27 maio. 2021c.

UNIOESTE. Universidade Estadual do Oeste do Paraná. Disponível em: https://www.unioeste.br/portal/ari/inicio. Acesso em: 26 out. 2020a.

YIN, R. K. Estudo de caso: planejamento e métodos. 3. ed. Porto Alegre: Bookman, 2005. 